\title{
Precarious work or sustainable livelihoods? Aligning Prestea's Programme with the development dialogue on artisanal and small-scale mining
}

\section{Obed Adonteng-Kissi and Barbara Adonteng-Kissi}

Abstract: Alternative livelihoods programmes (ALPs) are extensively executed in mining communities, often as models of development dialogue on artisanal and small-scale mining (ASM). This paper assesses whether Prestea's ALP aligns with the development dialogue on artisanal mining. The conceptual design of ALP in Ghana's Prestea is based on the notions of substitution, homogenous community, and impact scalability. This paper argues that the Prestea ALP is not aligned with the development dialogue on artisanal mining, and therefore it is difficult to understand the role and function of environmentally-damaging behaviours within livelihood strategies. The paper contends that it would be appropriate to concentrate on improving the existing artisanal miners' operation of those most susceptible to resource access restrictions. Further, it may be more prudent to utilize livelihood-centered interventions that create strong connections with sustainable development as a way of creating regular community engagements. Additionally, this paper argues that the term for the intervention programme on artisanal mining should be replaced with the broader term 'livelihood-centered intervention'. The replacement of the term 'ALP' avoids the tacit belief that $A L P$ can adequately replace artisanal mining operations. Livelihood-centered intervention should not necessarily utilize alternative livelihoods as direct behavioural change instruments. 
Keywords: Sustainable livelihoods; precarious work; 'galamsey'; livelihood-centered intervention; artisanal miners; large-scale miners.

\section{Introduction}

In the advanced economies, the key perspectives of precarious work are related to variations in jobs in the formal sector such as income disparity and susceptibility to firing and unusual work activities. However, in the developing world like Ghana precarious work is usually connected more to the informal sector than the formal sector (Shapland et al. 2017). Furthermore, precarious work is linked with whether jobs reward above poverty wage (Castel 2017). On the other hand, a livelihood is deemed sustainable when it is able cope with and recover from stresses and shocks and preserve or improve its capabilities, assets, and actions now and later and refrain from depleting the natural resource base (Paton and Johnston 2017, Kanel and Niraula 2017, Simpson 2007, Serrat 2017). This article provides a critical synthesis of Golden Star Resources Company’s (GSR) alternative livelihoods program (ALP) in Prestea by establishing the precarity and insecurity or even the sustainability of the ALP and to explore how the design and application of the program aligns with development dialogue on artisanal mining. The relevance of this case is that Prestea is noted for violent confrontations with GSR over land use and thus ALP is expected to address the problem. Artisanal mining was no longer considered as exclusively a low-tech, labor-intensive mineral extraction and poor part of mining as an outcome of some innovative international dialogue on artisanal mining more than a decade ago. It is therefore necessary to answer the research question below:

Does the ALP in Prestea aligns with the development dialogue on artisanal mining? 
These research questions are critical in directing the analysis of the study owing to the need to develop scientific understanding of "rural livelihoods" and formulate mining policies to address them. The study reveals the following: (a) ALP is not aligning with the development dialogue on artisanal mining; (b) Artisanal miners are reluctant to exit the sector; (c) GSR's ALP is not sustainable; (e) Prestea's ALP is precarious work since it is incapable of coping with and recuperate from stresses and shocks; and (f) There is limited intake into Prestea's ALP.

The article is presented in ten sections and sets out to explore how the design and application of this ALP aligns with development dialogue on artisanal mining. In the first section, the aim and research question driving the article have been introduced. Section two discusses artisanal mining in Ghana, the model of ALP adopted by GSR and sustainability of this ALP. Section three tackles the mining community's expectations of GSR to address historical inequalities and widening of the distribution of business returns. Section four discusses international dialogue on artisanal mining. Section five presents the concept of sustainable livelihoods which provides a conceptual framework to the article. Section six presents the methods and research design of the study detailing what was done, how it was done, and why it was done. Section seven describes the study area. Section eight presents the main findings that emerged from the study. Section nine discusses the findings of the study. This article is concluded in section ten. Here the research is assessed for what it has revealed about whether ALP aligns with development dialogue on artisanal mining.

\section{Artisanal Mining, Alternative Livelihood Program (ALP) and Sustainable Development}

The government of Ghana imposed a temporary ban on "galamsey" shortly after the New Patriotic Party (NPP) assumed power on $7^{\text {th }}$ January 2017. The term "galamsey" is "an 
adulteration of the English phrase "gather them and sell” used in Ghana to refer to illegal, unlicensed and informal artisanal and small-scale mining” (McQuilken and Hilson 2016, 10). Licensed artisanal miners and unlicensed "galamsey” operators constitute the local artisanal mining sector (Medinilla 2016). The government further withdrew all small-scale mining licenses granted persons and entities during the last few days of the previous administration suggesting that due process was not followed (Amewu 2017). Therefore, the government directed that about $70 \%$ of small-scale miners needed to re-apply for new licenses if they wanted to operate (Amewu 2017). This was part of attempts to combat "galamsey" activities and to ensure sustained mining and protect the heavily polluted water bodies (Patel et al. 2016, Hilson 2013, 2012, Amewu 2017, Holden 2015). In this direction, “Operation Vanguard” which is a Special Task Force of 400 police and military men was formed to curb these activities (Amewu 2017). The government has extended the ban to allow for a holistic assessment of the industry, and how it may best be structured and regulated to become a sustainable source of livelihood (Amewu 2017).

\subsection{Artisanal Mining in Ghana}

The expansion of "galamsey" in Ghana has been characterized by two significant features. First, there is virtually a volatile expansion in space and number of people engaged in the operation (Fold, Jønsson, and Yankson 2014). The main cause of this expansion is poor government coordination and regulation (Corbett, O'Faircheallaigh, and Regan 2017). This problem is also partly due to fluidity in land ownership, control and rights (Adonteng-Kissi et al. 2017). Second, an unidentified but considerable percentage of the entire artisanal miners' production is carried out in a hidden zone where real production is technically illegal and informal (Hilson et al. 2017, Mantey et al. 2017, Peluso 2017). It is estimated that $90 \%$ of 
artisanal miners operate informally in Sub-Saharan Africa (Hilson 2013). Additionally, artisanal mining directly employs an estimated one million and supports about 4.5 million people in Ghana (McQuilken and Hilson 2016, Bansah, Yalley, and Dumakor-Dupey 2016). The difference between registered artisanal miners and "galamsey" operators is usually hard to establish as many registered persons continue to carry out illegal operations through informal exporters and intermediary buyers (Patel et al. 2016). This can be explained in the context of mining on land not approved for the operators but with intertwined trading channels (Fold, Jønsson, and Yankson 2014).

Recent anthropological studies confirm that operations of artisanal miners are very complicated and well organized (Hilson and Banchirigah 2009). These studies especially point out the heterogeneity of illegal artisanal mining in the context of age, sex, education, marital status and occupation (Verbrugge 2017). Furthermore, these studies reveal that there is a wellestablished social division of labor in the sector: people of different ages, sex, education, marital status and occupation have been engaged in a broad range of jobs, including as diggers, washers, middlemen, and downstream service people (Jønsson and Fold 2011). A significant number of the artisanal miners have completed their high school, technical training and/or hold university degrees (Hilson and Banchirigah 2009). The broad gender division of labor in artisanal mining expresses the perceived appropriateness of tasks for both women and men (Lahiri-Dutt 2015, Jenkins 2014, Fold et al. 2017). In recent times, involvement of women in artisanal mining has become common in Ghana with both positive and negative social implications (Hilson 2010). Women tend to dominate in processing activities such as panning, preparing the processing plant as well as the provision of auxiliary services such as cooking, cleaning, buying gold (Armah et al. 2016). Women’s tasks are the most labor intensive yet yield the lowest economic returns (Armah et al. 2016). 
In the 1980s, Ghana made the choice for a foreign investment-driven gold-mining sector (Adonteng-Kissi 2017). As a result, the Prestea mines had their mineral rights transferred to Canadian listed GSR in 1994 (Adonteng-Kissi, Adonteng-Kissi, and Asamoah 2016). The Prestea mines had been at the centre of fierce hostility after its former owner laid off 1,400 of its 1,800 workers in 1998 when it was encountering economic problems (Puplampu and Dashwood 2011). In March 2002, GSR shut down its underground mine and changed its operational direction to surface mining (Adonteng-Kissi and Ohene-Konadu 2015). The surface mining operations required relatively lower demand for labour force and therefore many local people were laid off (Dashwood and Puplampu 2010b). This resulted in expansion of galamsey (Dashwood and Puplampu 2010a) in an extremely unregulated fashion which had negative consequence on the environment (Weaver et al. 2017). Thus, the artisanal miners were in fierce competition with formalised GSR relative to land use (Crisp 2017).

\subsection{Alternative Livelihoods Program (ALP)}

There are an estimated 15 million artisanal miners across the globe (Black et al. 2017). In Ghana, small-scale mining provides significant employment, income and foreign exchange earnings to many people (Hilson 2016). This has compelled policymakers to review their methods of handling illegal artisanal mining (Rupprecht 2017). Today, a significant number of policy-makers have acknowledged that cooperation and not hostility is the best answer to the problem (Dashwood and Puplampu 2010a, Jønsson and Fold 2011). Therefore, many governments, donor bodies and mining companies have designed and implemented ALP (Hilson and Banchirigah 2009). In Prestea, the orientation of GSR towards ALP has shifted policy development affecting local population to largely agricultural activities and skills training offered under this program. The company believes that this program will put local 
population in an enhanced position to receive steady incomes. The Golden Star Oil Palm Plantation (GSOPP) is a major scheme under the Prestea ALP funded autonomously with \$US1 per ounce of gold produced into the Golden Star Development Foundation (GSDF) (Medinilla 2016, Puplampu and Dashwood 2011). It is estimated that GSR has invested more than $\$ 800,000$ in the GSDF. The conditions in Ghana are suitable for planting oil palm since it is an indigenous plant. The GSR created the GSOPP as one of its important subsidiaries in 2006. The GSOPP is authorised to offer economic development through the operation of the ALP. It is intended that the operation of the current Prestea ALP would be able to exist beyond the life span of the Prestea mines. The program is founded on the smallholder system allowing each person to cultivate four hectares of oil palm which is demarcated for them under the program. The land is owned by the traditional chiefs who are in a special arrangement with GSR under the ALP to undertake oil palm plantations business. It is normal in Prestea for GSR to carry out expansive activities that usually make it necessary for artisanal miners or farmers to be relocated to another land. Farmers and artisanal miners can access other equally fertile land for food cropping under the GSOPP scheme. Therefore, a major aim of GSR's program is to provide alternative livelihoods to local population needing to be relocated in view of GSR's mining activities and to offer employment to the youth and local population who could otherwise undertake "galamsey" operation. More than \$2 million had been invested in the GSOPP, and 732 hectares had been planted as at February 2010 (Puplampu and Dashwood 2011). Furthermore, GSR has harvested 80,000 silkworm eggs as part of the ALP which is geared towards supporting local population in the catchment areas to be self-sufficient and generate employment prospects for the local people. Additionally, grass-cutter rearing, other animal husbandry, brewing and variety of cassava plantations have received substantial attention under the ALP. Another component of the ALP is skills training such as batik and soap making, masonry, electrical and plumbing works and mobile phone repairs which also 
benefits from the \$US1 per ounce of gold transferred into the GSDF. Nevertheless, the implementation of the ALP in Prestea have failed to (a) mobilize major players, (b) organize resources; (c) developing fresh institutions and local systems through dialogue and strategic action; (d) offer local ownership and control; (e) and develop local markets. Helmsing (2003) points out that the success of ALPs is based on policymakers' abilities to undertake the abovementioned.

ALP may be categorised into 3 broad and overlapping groups namely (i) alternatives, (ii) compensation, and (iii) incentives. Alternatives partly or totally substitute livelihoods for the recompenses that may usually be gained from the extraction of natural resources (Wright et al. 2016). The assumption usually underlying this method is that depletion of natural resources is mostly triggered by deprivation and limited choices (Weaver et al. 2017). Alternatives are segmented into 3 categories: the group that offer an alternative livelihood to replace the one being exploited, for example promoting skill training as an alternative to illegal artisanal mining operation; the group that offer an alternative occupation to decrease the necessity to extract natural resources for income (Roe et al. 2015). Thus, encouraging skills training, oil palm or cocoa farming is a substitute for expanding illegal artisanal mining (Morgan-Brown et al. 2010); and those that promote an alternative method of extracting a resource that has a lesser impact than the original method, for example promoting environmental-friendly mining to minimize the need to pollute the environment (DeWan et al. 2013).

Even though the rationale for the assumptions underpinning different programs vary, 3 major assumptions trigger the design and execution of many ALPs. First, it is assumed that offering alternatives will decrease population's need (Bacci 2017) and the crave to deplete natural resources and degrade the environment (Cleaver 2017). It is supposed that persons that are dependent on unsustainable activities will partially or completely choose to substitute an 
environmentally destructive activity for the more environmentally sustainable activity being offered if given the opportunity. This can be conceptualized in the context of the ALP rendering the opportunity cost of the destructive operation higher, if the sponsored alternative is certainly a more creative application of labor than the traditional or previous livelihood. In this context, the local population concerned may have an appreciation of exchanging temporary losses for lasting gain. The change of focus from operations that are not sustainable is supposed to raise family resilience in the long-term (Islam et al. 2017). Artisanal mining is compatible with the farming cycle since there is minimal barriers to entry coupled with flexibility in labor inputs (Decker 2017). The capacity to produce quick revenue suggests that artisanal mining contributes significantly to safety net function in times of difficulties (Schulte-Herbrüggen et al. 2013).

Second, there is the assumption that communities are homogenous, made-up of families with similar endowments and common characteristics (Waylen et al. 2013). Thus, it is supposed that an ALP executed at the community level will produce extensive acceptance and get to the interested resource operators. However, there are social and political structures at the community level that restrict access to resources and prospects (Béné et al. 2009). Considerable evidence suggests that natural resource usage varies in terms of the relative wealth of local population and that the most deprived families in a community are usually those who mostly rely on natural resources (Kümpel et al. 2010). Alternatives are required to provide compensations for the appropriate population such as those deeply reliant on the resource in question to produce sustainable results.

Third, it is supposed that aiming interventions at local population will scale up to population-level decreases in impact on the natural resources relative to sustainable development concerns (Wright et al. 2016). This supposes that local population will impact on a change from environmentally destructive operation at the family level and alterations by 
individual families will then scale up to population-level change. Nevertheless, intrafamily livelihood actions are dynamic. Creation of income by one person within a family can lead to a reorganisation of labor (Koch 2017) and enhanced attempts in extracting the resource in question by another family member. There are several exogenous issues that can water down the sustainability gains of an intervention at the community and population levels even if families do change their attitudes (Hill et al. 2012).

There may be a strong incentive for large-scale mining to enhance corporate reputations (Sethi, Martell, and Demir 2017) and impact on the direction of global discussions on sustainability because performance standards are usually voluntary (O'neill 2017). Nevertheless, this leads us to examine if the search for sustainability standards could contribute to de-contextualization of local development needs (Maconachie and Hilson 2013). Thus, there is a real threat that large-scale miners can put a disproportionate emphasis on reaching global performance standards, instead of concentrating on dealing with the exact social milieus within which their sustainability strategies are situated (Gilberthorpe and Banks 2012, Kirton and Trebilcock 2017).

\subsection{Sustainable Development}

The term "Sustainable Development was first introduced into international policy debate by the World Conservation Strategy (Charter and Tischner 2017). Sustainable development is characterised as development that meets the needs of the present without compromising the ability of the future generations to meet their own needs (Charter and Tischner 2017). Thus, the major quest that large-scale and small-scale miners presently must embrace is, ways of operation that do not damage the environment or undermine the development opportunities of local communities; and equitable distribution of the benefits among stakeholders while 
promoting economic growth. Large-scale miners are presently encountered with challenges to improve their environmental and social performance to safeguard integration of the concept of sustainable development and to deliver on their corporate social and environmental responsibilities in reaction to increasing pressure from international organisations, national governments, consumers, employees, local communities, NGOs and wider public (Yakovleva 2017).

ALP can only be sustainable if the range of "alternative” income-generating schemes that is being sponsored can stop local population from undertaking employment in artisanal mining and appeal to people already involved in artisanal mining operations. However, not many of the livelihood activities under the ALP are innovative, and they offer negligible added value to deprived local populations. Alternative livelihoods have generally sought to develop subsistence agrarian activities and skills training with the wrong assumption that all targeted groups are interested in agrarian activities and certain skills training. It is quite challenging task contrary to the understandings of large-scale miners, donor agencies and government views regarding the extremely chaotic nature of artisanal mining. Current anthropological studies indicate that artisanal mining activities are very complex and well organized (Spiegel 2017). These studies especially elucidate the heterogeneity of illegal artisanal mining communities in the context of the ethnic backgrounds, levels of skills and workers' lifestyles (Chuhan-Pole, Dabalen, and Land 2017).

Agrarian activities such as oil palm plantation, brewing, animal husbandry and silkworm cultivation under the ALP are not sustainable because there seems to be an idealistic anticipation that all local populations would give up artisanal mining if provided with ALP at the institutional level. Local people do not perceive this ALP as means to bring economic development and improved livelihoods. It is an undeniable fact that a significant number of people will not give up artisanal mining in the short term irrespective of the provision of ALP. 
In view of the income-generating possibility, some local people have invested substantial resources in equipment and operations which they would not want to forfeit. Therefore, legalized artisanal mining must be provided as an alternative. Furthermore, the silkworm cultivation under the ALP is not sustainable. Thus, the start-up capital that is normally offered by GSR for silkworm farming is inadequate. It usually takes up to a year to start making profit and therefore, makes it unsuitable alternative for deprived local populations.

Second, the skills training is unsustainable in Prestea since many graduates of the program cannot find contracts. The ALP is incapable of providing people with the equivalence of what they receive as "galamsey" operators and therefore consider the ALP as precarious work. Moreover, artisanal miners themselves are not included in livelihood exercises. The current procedure for re-skilling and training is selective in the catchment areas which is highly complex, and where communities are undoubtedly interlinked. There should not be a distinction between the supposed “catchment areas” and "galamsey” communities because they are not mutually exclusive. GSR does not have the full knowledge about the existence of skills among Prestea's artisanal miners. A significant number of artisanal miners in Prestea are trained with specialized skills, contrary to the popular notion that most artisanal miners are illiterates. Artisanal mining has shown to be a necessary source of income for those workers laid off when the Prestea underground mines was shut down, providing huge number of local population with jobs.

\section{Community Expectations}

Mining communities are increasingly expecting large-scale miners to deal with historical inequalities; widen the distribution of business returns (Puplampu and Dashwood 2011) and execute community development projects which have historically been the responsibilities of 
governments (Maconachie and Hilson 2013). After the introduction of long-term structural adjustment programs in the 1980s (Cumming 2017), developing economies were weak, as measures were put in place to reduce spending and direct economic involvement of the state (Obeng-Odoom 2012). These measures were supposedly undertaken to bring about a shift towards the market allocation of resources and to offer an "enabling environment" for the private sector to boom (Maconachie and Hilson 2013). The expectation that large-scale miners can achieve a set of social, economic and environmental objectives remains influential guiding policy of many companies (Baah-Ennumh and Forson 2017). Thus, the execution of community development projects such as ALP by large-scale miners expresses a desire to improve the welfare of artisanal miners who are deprived in many ways (Baah-Ennumh and Forson 2017). These programs are geared toward filling these development vacuums, considering it as an opening to improve their reputations globally and reinforce their social license to operate (Maconachie and Hilson 2013). However, many researchers have expressed substantial concerns. Some of these concerns are in relation to the limited knowledge of largescale miners in the socio-cultural milieus of the local population (Tschakert 2009). Overemphasis on reaching global performance standards has resulted in development outcomes which are unsuitable and impractical at the local level (Gilberthorpe and Banks 2012). In turn, these have led to additional disintegration and inequality (Maconachie and Hilson 2013).

\section{International Dialogue on Artisanal Mining}

More than a decade ago, international donor organizations such as the World Bank, the United Nations, Yaoundé Vision Statement provided some innovative international dialogue on artisanal mining (Labonne 2002, 25-29). In light of this, while artisanal mining was no longer considered as exclusively a low-tech, labor-intensive mineral extraction and deprived part of 
mining (Labonne 2014), it was incorporated into rural livelihoods and local economic development (Hilson 2016). The sector was also considered as an income generating rural operation with the possibility of helping to achieve sustainable livelihoods and poverty reduction (Hilson and Banchirigah 2009, Verbrugge 2017, Starke 2016). The shift in policy needed to handle artisanal mining in the same way as large-scale mining (Hilson and McQuilken 2014). This argument was based on a strategic element of an inclusive, mineralsbased sustainable development in Africa (Carstens and Hilson 2009). Therefore, stakeholders in the discussions were expanded to include players such as those associated with poverty reduction, community development, gender, child labor, human rights and pollution (Labonne 2014). Policy development affecting artisanal miners shifted from mining connoisseurs' domination in 2003, in Yaounde', Cameroon (Buxton 2013). Additionally, many legal regimes in Africa had gone through reforms to reflect the new trend in developmental dialogue on artisanal miners in order to permit artisanal mining operations (Mutemeri et al. 2016, Verbrugge 2015), despite its relationship with the supposed environmental degradation (Hilson and McQuilken 2014).

A meeting of the technical taskforce to draft the new “Africa Mining Vision” to lay the groundwork for the First African Union Conference of Ministers Responsible for Mineral Resources Development was jointly convened from 20th to 22th August 2008 by the African Union (AU) and the United Nations Economic Commission for Africa (ECA). It was geared towards a sustainable and well-governed mining sector that efficiently gathered and organized resource rents that is harmless, healthy, gender \& ethnically inclusive, environmentally friendly, socially responsible and appreciated by surrounding communities (AU 2009).

Furthermore, selected donors, intergovernmental organizations (IGOs), and governments of developing economies were taking a fresh interest in the sector. International groups comprising of Oro Verde, Fairtrade International, and the Alliance for Responsible 
Mining (ARM) contributed to ethical supply chains for minerals, establishing the Fairtrade and Fair Mined Gold Standard and stressing the area's capacity to spearhead innovation and modification (Hilson, Hilson, and McQuilken 2016). In 2001, the World Bank’s Communities and Small-scale Mining initiative (CASM), launched a better understanding of the sector, envisaging sustainable livelihoods perspective to artisanal miners to react to the requirement for cross disciplinary answers to enhance coordination between the key players (Hilson and McQuilken 2014).

It is a major concern that many years after the establishment of CASM, it had not achieved its aims with the main artisanal mining matters being highjacked by non-traditional actors (Labonne 2014, Geenen and Radley 2014). Several development donors and programs do not engage with the sector, considering ASM livelihoods as undesirable and fearing that engagement may promote illegal or hazardous mining (Sippl 2016, Mayes and Chang 2014, Hilson and Osei 2014).

Legal regimes based on the development dialogue on artisanal miners have not been successful in Africa (Mutemeri et al. 2016). The failure of present legal regime to deal with the destructive impact of artisanal miners and enhance development results is at the core of this fiasco (Debrah, Watson, and Quansah 2014). Presently, the law regulating small-scale mining activities in Ghana is the Mineral and Mining Act, 2006 (Act 703). All the other laws have since been repealed by Section 112 of the current law, Mineral and Mining Act 703, 2006. This current law stipulates that irrespective of who owns the land upon or under which minerals are situated, the exercise of any mineral right requires, by law, a license to be granted by agents of the State and not the land owner.

\section{The Concept of Sustainable Livelihoods}


The concept of livelihoods has been redefined as multidimensional just like the concept of poverty (Davies et al. 2014). Many sustainable livelihoods approaches (SLAs) have been designed since the 1990s to conceptualize the many effects on people's livelihood strategies. They have the tendency to contain a theoretical framework together with a set of principles that direct livelihood analyses and ensuing interventions (Toner and Franks 2006). The UK Department for International Development designed the most prominent SLA (Carney, Patel, and Clarke 2008).

SLA focuses on a portfolio of actions that is probably going to be required if a family is to accomplish its livelihood objectives. Families diversify their livelihood operations for many reasons. Voluntary and proactive factors in reaction to fresh prospects or as a way of decreasing vulnerability by anticipating and ameliorating risks are some of the reasons. Others reasons are essential coping measures ensuing from worsening situations or unexpected shocks (Ellis 2000). Many families in the developing world prefer livelihood strategies that spread risk rather than maximize returns since they usually lack access to insurance (Barrett, Reardon, and Webb 2001). Spreading risk is done through undertaking a series of actions because it permits families to alter the blend and the significance of activities contingent on their situations at any point in time. Families are reluctant to desert a livelihood to concentrate on alternatives such as aquaculture that require significant investment and time to generate income if they are familiar with obtaining a meagre daily income from a livelihood (Torell et al. 2010).

Nevertheless, all livelihood decisions cannot be presumed to be exclusively made with the intention of attaining the optimal balance between material gains and risk. There are differences in attitudes relative to risk. Persons undertake certain operations for many reasons including satisfaction (Pollnac and Poggie 2008). Persons’ livelihood operations have certain implications which should eventually not be overlooked (Gough and McGregor 2007). It is essential to go beyond just considering a family's existing portfolio of livelihood operations 
and recognize that the livelihood path of every family will be distinct in trying to understand livelihood strategies. While some families will be “stepping up,” investing in and improving their present operations or "stepping out" by accruing adequate assets to launch into basically different operations, others will be "hanging in," continuing with the same operations purely to preserve their present standard of living (Dorward et al. 2009). A family's strategy at any given time is influenced by its aims and aspirations, level of demographic life cycle, assets, and the limitations imposed or prospects offered by social and political systems (Gough and McGregor 2007). Families in the stepping out group are more probably going to have the ability and assets to lessen the risks involved in migrating from an environmentally destructive operation to a different alternative.

However, those hanging in are possibly going to change at extreme degrees of resource depletion or if they are under considerable pressure owing to resource access restrictions. However, sustainable development practitioners may advance their understanding of the role and function of environmentally destructive attitudes within family livelihood portfolios by accepting a SLA and recognizing the diversified nature of livelihood strategies in the developing world. This involves giving the necessary attention to endogenous and exogenous tendencies, coupled with the power interactions, politics, and institutions both within sustainability programs and the larger landscape that decide the varying access to livelihood prospects by different populations (De Haan and Zoomers 2005).

\section{Methods}

The research was designed utilizing mixed methods research techniques to collect the needed data for the study. Mixed methods are important for building validity and reliability (Creswell and Poth 2017). Survey data was collected before conducting the key informant interviews to provide detailed explanation of the issues. This is known as sequential explanatory mixed- 
methods design and consists of two distinct phases: quantitative followed by qualitative (Creswell 2013). The logic by explaining that the suitable combination of data is to put forward consistent results for a holistic analysis (Rauscher and Greenfield 2009). It is useful for generating supplementary, explanatory data to augment the findings from the survey. Creswell (2013) points out that the mixing is the actual process of merging or combining the qualitative and quantitative data in the data collection, analysis, or explanation phases of the research process. The population of the study area is estimated at 35,760-local people and there are approximately 800 indigenes who have been part of the ALP (Adonteng-Kissi, AdontengKissi, and Asamoah 2016).

Individuals chose to enrol in GSR's ALP and the authors administered 80 questionnaires to a randomly selected sample of the 800 beneficiaries. The instrument was therefore pilot-tested before the actual surveying in rural and urban Ghana. In the pilot testing, the survey was administered on a small group of participants to check language, format, and timing. The randomly selected sample of the 800 beneficiaries is $10 \%$ of the local population who enrolled in the ALP and are broadly spread in the community. The $10 \%$ sample is a good representation of the beneficiaries of the ALP. Members of the community who could not read or write were assisted (via interpretation) to answer the questions. The ratings of the ALP are captured by the following variables: age of respondents, sex of respondents, marital status of respondents, educational profile and occupation of the respondents. Accurate data analysis that effectively addresses demographic profile and answers a research question is critical for any study. In this study, statistical demographic features and determinants of whether ALP in Prestea aligns with the development dialogue on artisanal mining were analysed with descriptive and inferential statistical techniques using the Stata Version 13 software.

The qualitative sample consists of 20 respondents 13 were males and 7 were females. Majority of the respondents were males because galamsey and farming are all male dominated 
occupations. Purposive Sampling was used for the selection of all the sample units deliberately identified to provide specific information about the study population. Tashakkori and Teddlie (2010) point out that purposive sampling techniques involve selecting certain units or cases based on a specific purpose rather than randomly. The following is the breakdown of the sample size; 5 management members of the large-scale mines were selected. The justification for the inclusion of GSR is that, they are the major large-scale mining company in the area whose concessions are encroached by the galamsey operators. Additionally, 5 members of galamsey operators were selected because they have operated in Ghana for centuries and they believe that mining is their cultural right. Galamsey operators have been violently confronting GSR since the inception its operations. The authors selected 5 community farmers because they are also involved in the conflict. Farming activities are affected by galamsey and GSR's mining activities. Next, 3 members the environmental NGOs were selected because they are civil society organization who have been advocating for good environmental practices by GSR and the galamsey operators. Finally, 2 members of registered artisanal miners were selected because they are occasionally accused of encroaching on farmlands and environmental pollution. Authors therefore made use of key informant interviews. Some of the key informants were people who have basic knowledge about the ALP and they gave basic and in some cases in-depth information to inform the study. All interview sections were tape recorded, transcribed, translated and complemented with an accurate note taking. An interview schedule, mainly consisting of open ended questions, were prepared and used for the interviews.

\section{Study Area}

GSR is a global gold mining and exploration company based in Toronto, Canada (AdontengKissi and Ohene-Konadu 2015). The firm's significant mining activities are situated in the Western Region of Ghana’s Ashanti Gold belt where it has two major operational hubs namely 
(i) Prestea and (ii) Wassa. GSR applies a blend of surface and underground mining. The Bogoso concession was acquired in 1999 while the Prestea underground mine and surface rights was purchased in 2001. Currently, GSR holds 90\% shares through its subsidiary Golden Star (Bogoso/Prestea) Limited (GSBPL) which manages its activities in Prestea and Bogoso. Additionally, GSR owns the Wassa Mine to the east of Bogoso/Prestea through a distinct subsidiary Golden Star (Wassa) Limited. GSR produced 261,000 ounces of gold in 2014 and estimates of the total reserves in its concession amounted to 2,140,000 ounces in 2015 (Dashwood and Puplampu 2010b).

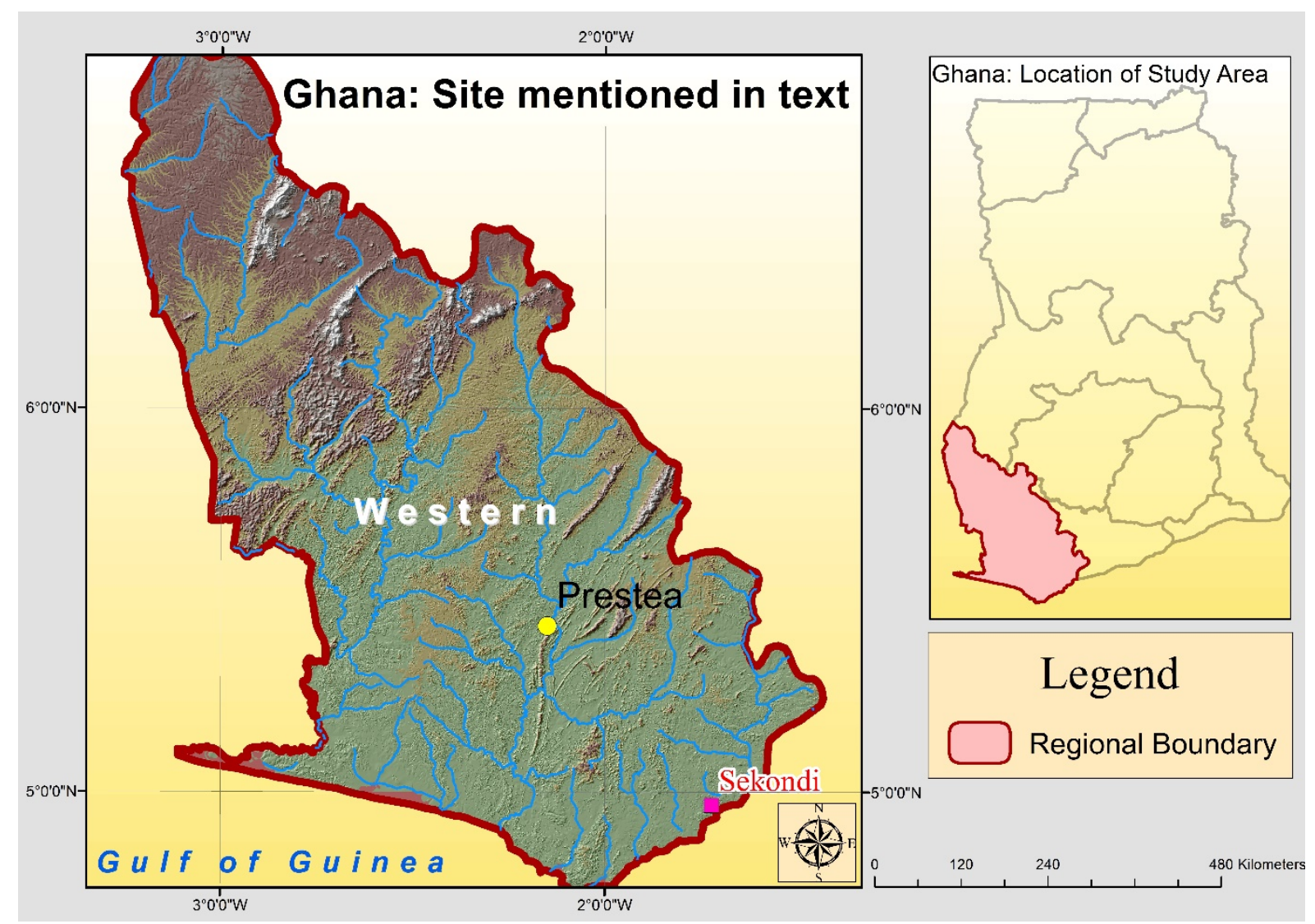

Figure 1: Map of Ghana with Location of Study

Cartography by: Samuel Kwesi Osei (2016), Department of Environmental Planning, Brandenburg Technical University, Germany.

The leases in Bogoso and Prestea catchment areas serve as the hometowns of many people covering 95 km2 (Bogoso) and 129 km2 (Prestea) respectively (Puplampu and Dashwood 
2011). The arrangement relating to the two concessions was a take-over by GSR from companies with a long history of strained relations with the host communities.

\section{Results}

The following variables; age groups, sex of respondents, participants' educational profile, marital status and occupational profile of respondents were captured in the ratings of the ALP in Prestea.

Table 1 presents perceptions on whether ALP aligns with the development dialogue on artisanal mining and age characteristic of participants. Participants $(\mathrm{N}=52)$ surveyed in Prestea (65\% of the sample) strongly disagreed that ALP aligns with the development dialogue on artisanal mining. Majority of the participants who strongly disagreed $(\mathrm{N}=22)$ in Prestea (27.50\% of the study sample) were between the ages of 19-26 years.

A significant number of the youth claimed that the ALP is not the model of international dialogue on artisanal miners that they were promised before the inception of the program. The current model of ALP is a precarious work that does not provide exit route out of poverty. A 22-year-old galamsey operator said:

I'm not interested in this ALP because GSR didn't involve us in its design and implementation. It is actually a precarious work that can't give me enough money. Galamsey on the other hand, provides me with enough income to look after my family. 
Many of the local population believe that the ALP is only a public relations gimmick. Another problem of the ALP is that the program has a limited intake. This they believe will not end the conflict.

Table 1: Perceptions on whether ALP Aligns with the Development Dialogue on artisanal mining and age characteristics of participants

Question: (i) Is it true that ALP aligns with the development dialogue on artisanal mining?

\begin{tabular}{llcccc}
\hline Age & $\begin{array}{l}\text { Strongly } \\
\text { Agree }(\%)\end{array}$ & $\begin{array}{c}\text { Agree } \\
(\%)\end{array}$ & $\begin{array}{l}\text { Disagree } \\
(\%)\end{array}$ & $\begin{array}{l}\text { Strongly } \\
\text { Disagree }(\%)\end{array}$ & $\begin{array}{c}\text { Indifferent } \\
(\%)\end{array}$ \\
\hline $19-26$ & $1(1.25)$ & $12(15.00)$ & $4(5.00)$ & $22(27.50)$ & $0(0.00)$ \\
$27-34$ & $0(0.00)$ & $3(3.75)$ & $5(6.25)$ & $20(25.00)$ & $0(0.00)$ \\
$35-42$ & $0(0.00)$ & $1(1.25)$ & $1(1.25)$ & $7(8.75)$ & $0(0.00)$ \\
$43-50$ & $0(0.00)$ & $0(0.00)$ & $1(1.25)$ & $3(3.75)$ & $0(0.00)$ \\
\hline Total & $1(1.25)$ & $16(20.00)$ & $11(13.75)$ & $52(65.00)$ & $0(0.00)$
\end{tabular}

Table 2 shows perceptions on whether ALP aligns with the development dialogue on artisanal mining and sex profile of respondents. Majority of respondents (52) disagreed that ALP aligns with development dialogue on artisanal mining. Males (45) representing $56.25 \%$ of the study sample formed most of the study sample.

A significant number of participants believe that GSR have made false assumptions about the families in Prestea, thinking that simply substituting artisanal mining with skills training will address family livelihoods in the area. A galamsey man said: 
I'm a man with a family and therefore I must do everything possible to look after my wife and children. The so-called ALP is a precarious work that will perpetuate us in poverty. Attempting to substitute the livelihood of an indigene is not the solution to the current problem. GSR should be able to distinguish between the indigene and migrant families in this community.

According to participants, galamsey operators have been compelled to operate underground because of the crack-down on their activities by the security agencies. Thus, they are vulnerable to access and hence they apply other means to extract the resource.

Table 2 Perceptions on whether ALP Aligns with the Development Dialogue on artisanal mining and sex characteristics of participants

Question: (i) Is it true that ALP aligns with the development dialogue on artisanal mining?

\begin{tabular}{lccccc}
\hline Sex & $\begin{array}{l}\text { Strongly } \\
\text { Agree }(\%)\end{array}$ & $\begin{array}{l}\text { Agree } \\
(\%)\end{array}$ & $\begin{array}{l}\text { Disagree } \\
(\%)\end{array}$ & $\begin{array}{l}\text { Strongly } \\
\text { Disagree }(\%)\end{array}$ & $\begin{array}{c}\text { Indifferent } \\
(\%)\end{array}$ \\
\hline Male & $1(1.25)$ & $10(12.50)$ & $8(10.00)$ & $45(56.25)$ & $0(0.00)$ \\
Female & $0(0.00)$ & $6(7.50)$ & $3(3.75)$ & $7(8.75)$ & $0(0.00)$ \\
\hline Total & $1(1.25)$ & $16(20.00)$ & $11(13.75)$ & $52(65.00)$ & $0(0.00)$ \\
\hline
\end{tabular}

Table 3 presents perceptions on whether ALP aligns with development dialogue on artisanal mining and educational profile of study participants. Participants $(\mathrm{N}=52)$ surveyed in Prestea (65\% of the sample) strongly disagreed that ALP aligns with the development dialogue on artisanal mining. Majority of the participants who strongly disagreed (46.25\% of the study sample) came from participants with primary education. 
Many key informants indicated that GSR and the government should consider mining activities of the indigenes as part of their cultural heritage since artisanal mining is an age-old practice. A galamsey operator with primary education said:

ALP has failed woefully in this catchment area. I've been trained as an electrician under the ALP but I'm not utilizing my skills because there are no contracts for me. However, I'm now able to cater for my family with resources from "galamsey" activities. Do you think it's easy to stop me from engaging in galamsey? I'm educated up to only the primary level so it's not easy for me to find other jobs.

Additionally, many key informants suggested that it would be more practical to apply a strategy that will establish a strong connection between galamsey operation and sustainable development by creating regular community engagements.

Table 3 Perceptions on whether ALP Aligns with the Development Dialogue on Artisanal Mining and Educational Characteristics of Participants.

Question: (i) Is it true that ALP aligns with the development dialogue on artisanal mining?

\begin{tabular}{llcllc}
\hline Education & $\begin{array}{l}\text { Strongly } \\
\text { Agree }(\%)\end{array}$ & $\begin{array}{c}\text { Agree } \\
(\%)\end{array}$ & $\begin{array}{l}\text { Disagree } \\
(\%)\end{array}$ & $\begin{array}{l}\text { Strongly } \\
\text { Disagree }(\%)\end{array}$ & $\begin{array}{c}\text { Indifferent } \\
(\%)\end{array}$ \\
\hline Primary & $0(0.00)$ & $5(6.25)$ & $7(8.75)$ & $37(46.25)$ & $0(0.00)$ \\
Secondary & $0(0.00)$ & $11(13.75)$ & $3(3.75)$ & $15(18.75)$ & $0(0.00)$ \\
Tertiary & $1(1.25)$ & $0(0.00)$ & $1(1.25)$ & $0(0.00)$ & $0(0.00)$ \\
\hline Total & $1(1.25)$ & $16(20.00)$ & $11(13.75)$ & $52(65.00)$ & $0(0.00)$
\end{tabular}


Table 4 presents perceptions on whether ALP aligns with the development dialogue on artisanal mining and marital status of study participants. Participants $(\mathrm{N}=52)$ surveyed in Prestea $(65 \%$ of the sample) strongly disagreed that ALP aligns with the development dialogue on artisanal mining. Majority of the participants who strongly disagreed $(\mathrm{N}=36)$ in Prestea $(45 \%$ of the study sample) were married participants.

Some respondents suggested that GSR appears to be essentially using the ALPs as a direct instrument for behavioral change. They believe such a behavioral change concept of the ALP is not feasible because artisanal mining is the way of life of the people. A married farmer said:

Many marriages of graduates of the ALP are breaking down because those graduates cannot simply find contracts that will earn them income after graduation. Married people in this area are beginning to realize that if they want their marriages to survive then they must not depend on this precarious skill training under the ALP. I believe the structure of the existing artisanal mining should rather be streamlined to make it environmentally sustainable.

Participants suggested that GSR should not focus on the fixed assumptions of the ALP relative to the characteristics of the local population which are largely inaccurate and therefore do not represent the true nature of the people. 
Table 4 Perceptions on whether ALP Aligns with the Development Dialogue on Artisanal Mining and Marital Characteristics of Participants

Question: (i) Is it true that ALP aligns with the development dialogue on artisanal mining?

\begin{tabular}{lllllc}
\hline $\begin{array}{l}\text { Marital } \\
\text { Status }\end{array}$ & $\begin{array}{l}\text { Strongly } \\
\text { Agree }(\%)\end{array}$ & $\begin{array}{c}\text { Agree } \\
(\%)\end{array}$ & $\begin{array}{l}\text { Disagree } \\
(\%)\end{array}$ & $\begin{array}{l}\text { Strongly } \\
\text { Disagree }(\%)\end{array}$ & $\begin{array}{c}\text { Indifferent } \\
(\%)\end{array}$ \\
\hline Married & $1(1.25)$ & $10(12.50)$ & $9(11.25)$ & $36(45.00)$ & $0(0.00)$ \\
Single & $0(0.00)$ & $4(5.00)$ & $0(0.00)$ & $6(7.50)$ & $0(0.00)$ \\
Divorced & $0(0.00)$ & $0(0.00)$ & $1(1.25)$ & $1(1.25)$ & $0(0.00)$ \\
Separated & $0(0.00)$ & $0(0.00)$ & $0(0.00)$ & $2(2.50)$ & $0(0.00)$ \\
De-facto & $0(0.00)$ & $2(2.50)$ & $1(1.25)$ & $7(8.75)$ & $0(0.00)$ \\
\hline Total & $1(1.25)$ & $16(20.00)$ & $11(13.75)$ & $52(65.00)$ & $0(0.00)$
\end{tabular}

Table 5 presents perceptions on whether ALP aligns with the development dialogue on artisanal mining and occupational profile of study respondents. Participants $(\mathrm{N}=52)$ surveyed in Prestea (65\% of the sample) strongly disagreed that ALP aligns with the development dialogue on artisanal mining. Majority of the participants who strongly disagreed (52.50\% of the study sample) were artisanal mining participants. 
Management of GSR were evasive on the question of whether GSR's ALP aligns with international dialogue on artisanal mining because no management member could provide straightforward answer. One mine management superintendent said:

I don't want to talk about things, I don't know; I have not investigated whether the ALP in Prestea aligns with the development dialogue on artisanal mining although it was designed based on sustainability principles. What I can say is that we've replaced the galamsey activity with ALP because one common characteristic of the youth here is their engagement in galamsey which has negative impact on the environment.

This implies that the conceptual design of ALP in Ghana's Prestea is based on the notions of substitution, homogenous community, and impact scalability. Despite these assumptions, there are people who have reverted to galamsey operation because there are no contracts for graduates of the ALP. Some youth want to train in the ALP but they are discouraged because of the unavailability of contracts after graduation. A galamsey operator in one of the catchment areas said:

Those who get the opportunity to enroll in the ALP must be given the free hand to choose a livelihood. Learning trades like mobile phones repairs, masonry and carpentry should not be imposed on the local youth.

Many participants believe that the ALP is not serving any good purpose because it does not align with the international dialogue on artisanal mining. Thus, galamsey operators consider ALP as precarious work because it has failed to provide a decent wage. Table 5 Perceptions on whether ALP is Aligned with the Development Dialogue on artisanal mining and occupational characteristics of participants.

Question: (i) Is it true that ALP aligns with the development dialogue on artisanal mining? 


\begin{tabular}{llllll}
\hline Occupation & $\begin{array}{l}\text { Strongly } \\
\text { Agree }(\%)\end{array}$ & $\begin{array}{c}\text { Agree } \\
(\%)\end{array}$ & $\begin{array}{c}\text { Disagree } \\
(\%)\end{array}$ & $\begin{array}{l}\text { Strongly } \\
\text { Disagree }(\%)\end{array}$ & $\begin{array}{l}\text { Indifferent } \\
(\%)\end{array}$ \\
\hline ASM & $0(0.00)$ & $5(6.25)$ & $7(8.75)$ & $42(52.50)$ & $0(0.00)$ \\
Farming & $0(0.00)$ & $1(1.25)$ & $2(2.50)$ & $2(2.50)$ & $0(0.00)$ \\
Petty-Trading & $0(0.00)$ & $6(7.50)$ & $1(1.25)$ & $7(8.75)$ & $0(0.00)$ \\
Other & $1(1.25)$ & $4(5.00)$ & $1(1.25)$ & $1(1.25)$ & $0(0.00)$ \\
\hline Total & $1(1.25)$ & $16(20.00)$ & $11(13.75)$ & $52(65.00)$ & $0(0.00)$ \\
\hline
\end{tabular}

\section{Discussions}

The aim of this ALP intervention is to decrease artisanal miners' dependence on mineral resources, create economic gains, and improve local support for sustainable development. Authors' study results indicate that, although the ALP in Prestea remains a crucial strategy in both global and sustainability perspectives, it is not aligning with the development dialogue on artisanal mining. Thus, this ALP is not perceived to bring economic development and improved livelihoods of local population. This finding is consistent with literature elsewhere in the world (Labonne 2014). More than two decades on from the Yaoundé Vision, livelihood policies do not align with development dialogue on artisanal mining and local economic development as stipulated in the Yaoundé Vision Statement (Mutemeri et al. 2016). A substantial literature has come up, on ALPs, poverty and artisanal mining in sub-Saharan Africa indicating that the inducement arrangements of ALPs have many things in common with the development dialogue on artisanal miners, yet the program is perceived as precarious work by the local population (Hilson 2011). Elsewhere, Hilson (2011) finds that ALP has been designed based on skills training and farm activities which local population clearly consider as precarious work. 
What is significant in this study is that regardless of age, sex, education, marital status and occupation, $65 \%$ of the sample size strongly disagreed that GSR's ALP aligns with development dialogue on artisanal mining. Thus, the ALP in Prestea has failed to enhance the economic development and improved the welfare of the local population irrespective of age, sex, education, marital status and occupation. The implication is that, it is irrelevant for scholars of artisanal mining and livelihoods to improve intervention targeting based on age, sex, education, marital status and occupation and learn more about the social and environmental structure within which family livelihood strategies are found.

Artisanal miners form a significant majority (67.50\%) of the occupations captured under this study and followed by farming (6.25\%). Artisanal miners therefore strongly disagreed that GSR's ALP aligns with development dialogue on artisanal mining. Therefore, this ALP has failed to enhance the livelihoods of local people and earn them income. The implication is that, there is the need for further empirical research to understand properly the social milieu of the local population relative to culture of work or occupation which is consistent with literature elsewhere (Baah-Ennumh and Forson 2017). This finding is consistent with literature elsewhere in the world. For example, scholars suggest that artisanal miners should be targeted for intervention-centred programs to reduce poverty and address environmental challenges and depletion of natural resources (Cochrane 2017, Sierra et al. 2017, Sippl 2016).

Furthermore, the results of authors' analysis present clear and consistent evidence that artisanal miners are reluctant to exit the activity. Several studies have investigated how local population react to situations of depleting resources and the whether ALP influences this decision (Muallil, Cleland, and Aliño 2013). As a result, Diallo (2017) find no sign that artisanal miners are willing to give up mining. These studies emphasize the complex relation between occupational diversity and local population's interaction with the environment. These 
complexities guarantee that implementing a single strategy of offering ALP as a blanket solution to curtailing environmental pollution and reducing poverty is not likely to succeed. It is therefore important to recognize the complexity inherent in intervening to alter local population's livelihood strategies. This is further supported by studies from elsewhere around the world which show the complex relations between ALP portfolios and people's environmental impacts (Cinner 2014).

Moreover, Berkes (2012) finds that dwelling on livelihoods in the context of financial inducement masks the complexity of rural livelihoods in mining communities. Furthermore, the results of authors' analysis present clear and consistent evidence that livelihoods focused intervention is likely to succeed if the existing artisanal mining is improved to address environmental issues and reduce poverty. Cinner (2014) finds that investments in ALP are likely to have high benefits if properly targeted, however, can also produce precarious work if inappropriately targeted.

The results of authors' analysis present clear and consistent evidence of the study that indicate that GSR's ALP is not sustainable. Local perceptions on ALP in Prestea does not support enhanced economic development and improved livelihoods of local people. Wright et al. (2016) find that ALPs promote unsustainable solutions that are ill-adapted to local population's capacities, and limited market appeal which fail to reflect people’s aspirations for their future. Furthermore, Hilson (2011) finds ALP approach as impractical and unsustainable as the small farm-first strategy is presently at the core of sub-Sahara Africa's donor-driven poverty alleviation attempts. Additionally, literature elsewhere confirms that assumptions such as substitution, homogenous community and impact scalability in the design and implementation are likely to produce precarious work for the local population because it is outmoded. In a recent study on ALPs in Central Africa, 8 out of the 15 models were based on the hypothesis that the alternatives would offer the same or more income than hunting which 
implied that hunters no longer needed to hunt. (Wicander and Coad 2015). Nevertheless, the evidence indicates that the assumption of substitution is hardly tenable; the alternatives are rather turned into extra sources of income and depletion of the resource continues at similar degrees (Torell et al. 2010). Additionally, Berkes (2012) finds that livelihoods interventions are erroneously liken to "wants" and "needs" of the local population with financial gains and economic substitutes. Furthermore, Kareiva (2014) finds that livelihood interventions attempts to engage local population for utilitarian instead of moral or aesthetic factors.

Graduates of the ALP consider the program as precarious work because it is incapable of coping with and recuperate from stresses and shocks and maintain or enhance its capacities, assets, and activities presently and the future and refrain from depleting the natural resource base. Hilson (2011) finds that the precarity of ALP is based on activities which clearly have limited remunerative capacity such as beer brewing and animal husbandry. Generally, empirical literature on the micro-level impact of ALP find that alternatives have a negligible impact on local population. In recent times, disillusionment has increased in Prestea as GSR's ALP has been water down as having negligible, or even negative effects on the environment.

Additionally, this study reveals that there is limited intake into the ALP. In literature, Hilson and Banchirigah (2009) find solid evidence of limited intake of artisanal miners into ALP in Ghana. Moreover, some persons trained under the ALP have returned to "galamsey" activities. Banchirigah and Hilson (2010) find that most of the alternatives being promoted have been ineffective, lacking the appeal to draw people out of artisanal mining. Hilson (2011) finds that with their low barriers to entry, informal artisanal mining, which offer a range of employment prospects from labor-intensive to skilled posts such as accountants have been the preferred destinations of choice for rural African farm families during times of hardship.

\section{Conclusion}


It is significant to acknowledge that the ALP in Prestea does not align with the development dialogue on artisanal mining owing to the complexity associated with interventions that alter local population's livelihood strategies. The local perceptions of the ALP are lack economic prosperity and improved incomes of the people. Even if a livelihood program is accepted by the local population, it may be at a level of livelihood substitution that only offers precarious work. Families are thus still dependent on income from other sources, including artisanal mining, to defray other cost. Wrongly designed programs do not suit local population's capabilities and produces results that are not sustainable. ALP may be unattractive to local population if it is badly tailored and does not reflect local aspirations. The inadequacies in the design of the concept of ALP is triggered by insufficient understanding of the social milieu of the local population and ill-conceived livelihood programs. The assumptions in the design and implementation of many ALPs are based on misplaced assumptions.

It may be more suitable to pursue livelihood-centred interventions by targeting the most vulnerable to resource access restrictions by providing them with a form of compensation. This is because development dialogue on artisanal mining reminds large-scale miners of their ethical responsibility not to deprive local populations of their livelihoods. Improving the existing livelihood strategies of this group through enrichment and efficiency of livelihood activities, or minimizing risk, may also contribute to making them more resilient to social dislocation. Large-scale miners should focus on local populations in the design of ALPs by dealing with actual and local defined needs. This should produce productive social results; however, it is improbable that only these interventions will do when it comes to achieving sustainable development outcomes. The actual value of livelihood-centred interventions from a sustainable development perspective should be able to change local attitudes toward environmental sustainability, decrease conflict and increase cooperation between large miners and the local population. 
Knowledge from local population, policy makers and researchers with the goal of promoting more effective livelihoods-centred interventions is needed to tackle poverty and create trust implying that knowledge itself must be neutral, balanced, and respectful of varied sources. This model centred on the design of scientific and hybrid knowledge is extremely significant to local and policy maker needs. There can be a more suitable and genuine objective of livelihoods program than applying these interventions as a direct attitudinal change instrument. Such interventions might be regarded as a form of compensation to join forces with sustainability agenda. The application of these approaches should not disregard the wider context since it is usually a macrolevel procedure. These are usually outside the purview of livelihoods-centred interventions which influence how livelihoods paths evolve. Additionally, external tendencies can eventually offset the sustainability benefits of an intervention, even if there is alteration in local livelihoods strategies. The broader procedures of social and environmental change must thus be taken into consideration if livelihoods-centred interventions are to be locally relevant and effective in the context of sustainable development. Finally, changing from the term "ALP” to the broader term livelihood-centred intervention removes the core and naïve assumption of substitution. Authors are convinced that this alteration will result in a more accurate and nuanced theories of change in program design and evaluation. This minor terminological alteration would help large-scale miners to work with local population to advance both their welfare and environmental sustainability.

\section{References}

Adonteng-Kissi, Obed. 2017. "Poverty and mine’s compensation package: Experiences of local farmers in Prestea mining community." Resources Policy 52:226-234.

Adonteng-Kissi, Obed , Barbara Adonteng-Kissi, and Edward Asamoah. 2016. "Mining versus Farming: An Analysis of the Farmers' Livelihood System." Sustainability in Economic, Social, and Cultural Context 12 (2):31-46. doi: 10.18848/2325-1115/CGP.

Adonteng-Kissi, Obed, Barbara Adonteng-Kissi, Mohammed Kamal Jibril, and Samuel Kwesi Osei. 2017. "Communal Conflict Versus Education: Experiences of Stakeholders in Ghana’s Bawku Conflict." International Journal of Educational Development. 
Adonteng-Kissi, Obed, and Kofi Ohene-Konadu. 2015. "Assessing Community Relocation and Resettlement Programs for Managing Conflicts in the Prestea Mining Community." The International Journal of Sustainability Policy and Practice 11 (3):13-28.

Amewu, John Peter. 2017. Government to Extend Ban on Small Scale mining. edited by Latiff Iddris. Accra, Ghana: Joy News

Armah, Frederick Ato, Sheila A Boamah, Reginald Quansah, Samuel Obiri, and Isaac Luginaah. 2016. "Working conditions of male and female artisanal and small-scale goldminers in Ghana: examining existing disparities." The Extractive Industries and Society 3 (2):464-474.

AU. 2009. Africa Mining Vision, Africa Union. In AU, Addis Ababa.

Baah-Ennumh, Theresa, and Joseph Ato Forson. 2017. "The impact of artisanal small-scale mining on sustainable livelihoods: a case study of mining communities in the TarkwaNsuaem municipality of Ghana." World Journal of Entrepreneurship, Management and Sustainable Development 13 (3).

Bacci, Massimo Livi. 2017. A concise history of world population: John Wiley \& Sons.

Banchirigah, Sadia Mohammed, and Gavin Hilson. 2010. "De-agrarianization, reagrarianization and local economic development: Re-orientating livelihoods in African artisanal mining communities." Policy Sciences 43 (2):157-180.

Bansah, KJ, AB Yalley, and N Dumakor-Dupey. 2016. "The hazardous nature of small scale underground mining in Ghana." Journal of Sustainable Mining 15 (1):8-25.

Barrett, Christopher B, Thomas Reardon, and Patrick Webb. 2001. "Nonfarm income diversification and household livelihood strategies in rural Africa: concepts, dynamics, and policy implications." Food policy 26 (4):315-331.

Béné, Christophe, Elisabeth Steel, Billy Kambala Luadia, and Ann Gordon. 2009. "Fish as the "bank in the water"-Evidence from chronic-poor communities in Congo." Food policy 34 (1):108-118.

Berkes, Fikret. 2012. "Poverty reduction isn't just about money: community perceptions of conservation benefits." Biodiversity conservation and poverty alleviation: Exploring the evidence for a link:270-285.

Black, Paleah, Myrianne Richard, Ricardo Rossin, and Kevin Telmer. 2017. "Assessing occupational mercury exposures and behaviours of artisanal and small-scale gold miners in Burkina Faso using passive mercury vapour badges." Environmental research 152:462-469.

Buxton, Abbi. 2013. "Responding to the challenge of artisanal and small-scale mining." How can knowledge networks help.

Carney, AS, N Patel, and R Clarke. 2008. "Foreign bodies in the ear and the aerodigestive tract in children." Gleeson M: Scott-Brown's Otorhinolaryngology, Head and Neck Surgery $1: 1188$.

Carstens, Johanna, and Gavin Hilson. 2009. "Mining, grievance and conflict in rural Tanzania." International Development Planning Review 31 (3):301-326.

Castel, Robert. 2017. From manual workers to wage laborers: transformation of the social question: Routledge.

Charter, Martin, and Ursula Tischner. 2017. Sustainable solutions: developing products and services for the future: Routledge.

Chuhan-Pole, Punam, Andrew L Dabalen, and Bryan Christopher Land. 2017. Mining in Africa: Are Local Communities Better Off?: World Bank Publications.

Cinner, Joshua. 2014. "Coral reef livelihoods." Current Opinion in Environmental Sustainability 7:65-71.

Cleaver, Frances. 2017. Development through bricolage: rethinking institutions for natural resource management: Routledge. 
Cochrane, Glynn. 2017. "Artisanal Mining and Closure." In Anthropology in the Mining Industry, 135-160. Springer.

Corbett, Tony, Ciaran O'Faircheallaigh, and Anthony Regan. 2017. "'Designated areas' and the regulation of artisanal and small-scale mining." Land Use Policy 68:393-401.

Creswell, John W, and Cheryl N Poth. 2017. Qualitative inquiry and research design: Choosing among five approaches: Sage publications.

Creswell, JW. 2013. Research Design: Qualitative, Quantitative, and Mixed Methods Approaches. 4th ed. 2455 Teller Road, Thousands Oaks, California 91320: Sage Publications Incorporation.

Crisp, Jeff. 2017. The Story of an African Working Class: Ghanaian Miners' Struggles 18701980: Zed Books Ltd.

Cumming, Gordon. 2017. Aid to Africa: French and British policies from the Cold War to the new millennium: Taylor \& Francis.

Dashwood, HS, and BB Puplampu. 2010a. Corporate Social Responsibility at Golden Star Resources, Ghana: a multiperspective collaborative case study report. Ryerson University, http://www. ryerson. ca/csrinstitute/current_projects/Dfait_ch3_GSR_ Ghana. pdf.

Dashwood, HS, and BB Puplampu. 2010b. Corporate social responsibility at golden star resources, Ghana: A multiperspective collaborative case study report (pp. 1-66).

Davies, Tammy E, Ioan RA Fazey, Will Cresswell, and Nathalie Pettorelli. 2014. "Missing the trees for the wood: Why we are failing to see success in pro-poor conservation." Animal Conservation 17 (4):303-312.

De Haan, Leo, and Annelies Zoomers. 2005. "Exploring the frontier of livelihoods research." Development and change 36 (1):27-47.

Debrah, AA, I Watson, and DPO Quansah. 2014. "Comparison between artisanal and smallscale mining in Ghana and South Africa: lessons learnt and ways forward." Journal of the Southern African Institute of Mining and Metallurgy 114 (11):913-921.

Decker, Benji. 2017. "Collaborative Production in the 21st Century." Master's Thesis Research, New York University.

DeWan, Amielle, Kevin Green, Xiaohong Li, and Daniel Hayden. 2013. "Using social marketing tools to increase fuel-efficient stove adoption for conservation of the golden snub-nosed monkey, Gansu Province, China." Conservation Evidence 10:32-36.

Diallo, Penda. 2017. "Social insecurity, stability and the politics in West Africa: A case study of artisanal and small-scale diamond mining in Guinea, 1958-2008." The Extractive Industries and Society.

Dorward, Andrew, Simon Anderson, Yolanda Nava Bernal, Ernesto Sánchez Vera, Jonathan Rushton, James Pattison, and Rodrigo Paz. 2009. "Hanging in, stepping up and stepping out: livelihood aspirations and strategies of the poor." Development in Practice 19 (2):240-247.

Ellis, Frank. 2000. Rural livelihoods and diversity in developing countries: Oxford university press.

Fold, Niels, Albert NM Allotey, Per Kalvig, and Lasse Moeller-Jensen. 2017. "Grounding institutions through informal practice: Credibility in artisanal mining of aggregates, Ghana." Land Use Policy.

Fold, Niels, Jesper Bosse Jønsson, and Paul Yankson. 2014. "Buying into formalization? State institutions and interlocked markets in African small-scale gold mining." Futures 62:128-139.

Geenen, Sara, and Ben Radley. 2014. "In the face of reform: What future for ASM in the eastern DRC?" Futures 62:58-66. 
Gilberthorpe, Emma, and Glenn Banks. 2012. "Development on whose terms?: CSR discourse and social realities in Papua New Guinea's extractive industries sector." Resources Policy 37 (2):185-193.

Gough, Ian, and J Allister McGregor. 2007. Wellbeing in developing countries: from theory to research: Cambridge University Press.

Helmsing, AHJ. 2003. "Local economic development: new generations of actors, policies and instruments for Africa." Public Administration and Development 23 (1):67-76.

Hill, NAO, JM Rowcliffe, HJ Koldewey, and EJ Milner-Gulland. 2012. "The interaction between seaweed farming as an alternative occupation and fisher numbers in the Central Philippines." Conservation Biology 26 (2):324-334.

Hilson, G. 2010. "Child Labour in African Artisanal Mining Communities: Experiences from Northern Ghana." Development and Change 41 (3):445-473.

Hilson, Gavin. 2011. "Artisanal Mining, Smallholder Farming And Livelihood Diversification In Rural Sub-Saharan Africa: An Introduction." Journal of international development 23 (8):1031-1041.

Hilson, Gavin. 2012. "Poverty traps in small-scale mining communities: the case of subSaharan Africa." Canadian Journal of Development Studies/Revue canadienne d'études du développement 33 (2):180-197.

Hilson, Gavin. 2013. "' Creating" Rural Informality: The Case of Artisanal Gold Mining in Sub-Saharan Africa." SAIS Review of International Affairs 33 (1):51-64.

Hilson, Gavin. 2016. "Farming, small-scale mining and rural livelihoods in Sub-Saharan Africa: a critical overview." The Extractive Industries and Society 3 (2):547-563.

Hilson, Gavin, and Sadia Mohammed Banchirigah. 2009. "Are alternative livelihood projects alleviating poverty in mining communities? Experiences from Ghana." The Journal of Development Studies 45 (2):172-196.

Hilson, Gavin, Abigail Hilson, Roy Maconachie, James Mcquilken, and Halima Goumandakoye. 2017. "Artisanal and small-scale mining (ASM) in sub-Saharan Africa: Re-conceptualizing formalization and 'illegal'activity." Geoforum 83:80-90.

Hilson, Gavin, Abigail Hilson, and James McQuilken. 2016. "Ethical minerals: Fairer trade for whom?" Resources Policy 49:232-247.

Hilson, Gavin, and James McQuilken. 2014. "Four decades of support for artisanal and smallscale mining in sub-Saharan Africa: a critical review." The Extractive Industries and Society 1 (1):104-118.

Hilson, Gavin, and Lydia Osei. 2014. "Tackling youth unemployment in sub-Saharan Africa: Is there a role for artisanal and small-scale mining?" Futures 62:83-94.

Holden, William N. 2015. "Mining amid typhoons: Large-scale mining and typhoon vulnerability in the Philippines." The Extractive Industries and Society 2 (3):445-461.

Islam, Mir Rabiul, Valerie Ingham, John Hicks, and Ian Manock. 2017. "The changing role of women in resilience, recovery and economic development at the intersection of recurrent disaster: A case study from Sirajgang, Bangladesh." Journal of Asian and African Studies 52 (1):50-67.

Jenkins, Katy. 2014. "Women, mining and development: an emerging research agenda." The Extractive Industries and Society 1 (2):329-339.

Jønsson, Jesper Bosse, and Niels Fold. 2011. "Mining 'from below’: Taking Africa’s artisanal miners seriously." Geography Compass 5 (7):479-493.

Kanel, Keshav Raj, and Durga Raj Niraula. 2017. "Can rural livelihood be improved in Nepal through community forestry?" Banko janakari 14 (1):19-26.

Kareiva, Peter. 2014. "New conservation: setting the record straight and finding common ground." Conservation Biology 28 (3):634-636. 
Kirton, John J, and Michael J Trebilcock. 2017. Hard choices, soft law: Voluntary standards in global trade, environment and social governance: Routledge.

Koch, Max. 2017. Roads to post-Fordism: labour markets and social structures in Europe: Routledge.

Kümpel, Noëlle F, EJ Milner-Gulland, Guy Cowlishaw, and J Marcus Rowcliffe. 2010. "Incentives for hunting: the role of bushmeat in the household economy in rural Equatorial Guinea." Human Ecology 38 (2):251-264.

Labonne, Beatrice. 2002. "Synthesis report." Seminar on artisanal and small-scale mining in Africa. Identifying best practices and building the sustainable livelihoods of communities. Yaounde, Cameroon.

Labonne, Beatrice. 2014. "Who is afraid of artisanal and small-scale mining (ASM)?" The Extractive Industries and Society 1 (2):121-123.

Lahiri-Dutt, Kuntala. 2015. "The Feminisation of Mining." Geography Compass 9 (9):523541.

Maconachie, Roy, and Gavin Hilson. 2013. Editorial introduction: the extractive industries, community development and livelihood change in developing countries. Oxford University Press.

Mantey, J, F Owusu-Nimo, KB Nyarko, and A Aubynn. 2017. "Operational dynamics of "Galamsey" within eleven selected districts of western region of Ghana." Journal of Mining and Environment 8 (1):11-34.

Mayes, Warren, and Nigel Chang. 2014. "Discovering Sepon: Cultural heritage management and the making of a modern mine." The Extractive Industries and Society 1 (2):237248.

McQuilken, J, and G Hilson. 2016. Artisanal and Small-scale Gold Mining in Ghana. Evidence to inform an "Action Dialogue". London: IIED.

Medinilla, Alfonso. 2016. "Mining and community-based agribusiness for development."

Morgan-Brown, Theron, Susan K Jacobson, Kenneth Wald, and Brian Child. 2010. "Quantitative assessment of a Tanzanian integrated conservation and development project involving butterfly farming." Conservation Biology 24 (2):563-572.

Muallil, Richard N, Deborah Cleland, and Porfirio M Aliño. 2013. "Socioeconomic factors associated with fishing pressure in small-scale fisheries along the West Philippine Sea biogeographic region." Ocean \& coastal management 82:27-33.

Mutemeri, Nellia, Joshua Z Walker, Nancy Coulson, and Ingrid Watson. 2016. "Capacity building for self-regulation of the Artisanal and Small-Scale Mining (ASM) sector: A policy paradigm shift aligned with development outcomes and a pro-poor approach." The Extractive Industries and Society 3 (3):653-658.

O'neill, Kate. 2017. The environment and international relations: Cambridge University Press.

Obeng-Odoom, Franklin. 2012. "Neoliberalism and the urban economy in Ghana: Urban employment, inequality, and poverty." Growth and Change 43 (1):85-109.

Patel, Kayla, John Rogan, Nicholas Cuba, and Anthony Bebbington. 2016. "Evaluating conflict surrounding mineral extraction in Ghana: assessing the spatial interactions of large and small-scale mining." The Extractive Industries and Society 3 (2):450-463.

Paton, Douglas, and David Johnston. 2017. Disaster resilience: an integrated approach: Charles C Thomas Publisher.

Peluso, Nancy Lee. 2017. "Entangled Territories in Small-Scale Gold Mining Frontiers: Labor Practices, Property, and Secrets in Indonesian Gold Country." World Development.

Pollnac, Richard B, and John J Poggie. 2008. "Happiness, well-being and psychocultural adaptation to the stresses associated with marine fishing." Human Ecology Review:194200. 
Puplampu, Bill Buenar, and Hevina S Dashwood. 2011. "Organizational antecedents of a mining firm's efforts to reinvent its CSR: The case of golden star resources in Ghana." Business and Society Review 116 (4):467-507.

Rauscher, L., and BH. Greenfield. 2009. "Advancements in contemporary physical therapy research: use of mixed methods designs." Physical Therapy 89 (1):91-100.

Roe, Dilys, Francesca Booker, Mike Day, Wen Zhou, Sophie Allebone-Webb, Nicholas AO Hill, Noelle Kumpel, Gillian Petrokofsky, Kent Redford, and Diane Russell. 2015. "Are alternative livelihood projects effective at reducing local threats to specified elements of biodiversity and/or improving or maintaining the conservation status of those elements?" Environmental Evidence 4 (1):22.

Rupprecht, SM. 2017. "Bench mining utilizing manual labour and mechanized equipment-a proposed mining method for artisanal small-scale mining in Central Africa." Journal of the Southern African Institute of Mining and Metallurgy 117 (1):25-31.

Schulte-Herbrüggen, Björn, Guy Cowlishaw, Katherine Homewood, and J Marcus Rowcliffe. 2013. "The importance of bushmeat in the livelihoods of West African cash-crop farmers living in a faunally-depleted landscape." PloS one 8 (8):e72807.

Serrat, Olivier. 2017. "The sustainable livelihoods approach." In Knowledge solutions, 21-26. Springer.

Sethi, S Prakash, Terrence F Martell, and Mert Demir. 2017. "An evaluation of the quality of corporate social responsibility reports by some of the world's largest financial institutions." Journal of Business Ethics 140 (4):787-805.

Shapland, Joanna, Joanna Shapland, Jason Heyes, and Jason Heyes. 2017. "How close are formal and informal work?" International Journal of Sociology and Social Policy 37 (7/8):374-386.

Sierra, C, O Ruíz-Barzola, M Menéndez, JR Demey, and JL Vicente-Villardón. 2017. "Geochemical interactions study in surface river sediments at an artisanal mining area by means of Canonical (MANOVA)-Biplot." Journal of Geochemical Exploration 175:72-81.

Simpson, Murray C. 2007. "An integrated approach to assess the impacts of tourism on community development and sustainable livelihoods." Community development journal 44 (2):186-208.

Sippl, Kristin. 2016. "Civil society governance decisions: certification organization response to artisanal and small-scale gold mining." Boston University.

Spiegel, Samuel J. 2017. "EIAs, power and political ecology: Situating resource struggles and the techno-politics of small-scale mining." Geoforum 87:95-107.

Starke, Linda. 2016. Breaking new ground: Mining, minerals and sustainable development: Routledge.

Tashakkori, A, and C Teddlie. 2010. Sage Handbook of Mixed Methods in Social \& Behavioral Research. 2nd ed. 2455 Teller Road, Thousand Oaks, California 91320: Sage Publications Incorporation.

Toner, Anna, and Tom Franks. 2006. "Putting livelihoods thinking into practice: implications for development management." Public Administration and Development 26 (1):81-92.

Torell, Elin, Brian Crawford, Dawn Kotowicz, Maria D Herrera, and James Tobey. 2010. "Moderating our expectations on livelihoods in ICM: experiences from Thailand, Nicaragua, and Tanzania." Coastal Management 38 (3):216-237.

Tschakert, Petra. 2009. "Digging Deep for Justice: A Radical Re-imagination of the Artisanal Gold Mining Sector in Ghana." Antipode 41 (4):706-740.

Verbrugge, Boris. 2015. "Undermining the state? Informal mining and trajectories of state formation in Eastern Mindanao, Philippines." Critical Asian Studies 47 (2):177-199. 
Verbrugge, Boris. 2017. "Towards a negotiated solution to conflicts between large-scale and small-scale miners? The Acupan contract mining project in the Philippines." The Extractive Industries and Society 4 (2):352-360.

Waylen, Kerry Ann, Anke Fischer, Philip JK McGowan, and Eleanor J Milner-Gulland. 2013. "Deconstructing community for conservation: why simple assumptions are not sufficient." Human Ecology 41 (4):575-585.

Weaver, Paul, Leo Jansen, Geert Van Grootveld, Egbert Van Spiegel, and Philip Vergragt. 2017. Sustainable technology development: Routledge.

Wicander, Sylvia, and Lauren Coad. 2015. Learning our lessons: a review of alternative livelihood projects in Central Africa: IUCN.

Wright, Juliet H, Nicholas AO Hill, Dilys Roe, J Marcus Rowcliffe, Noëlle F Kümpel, Mike Day, Francesca Booker, and EJ Milner-Gulland. 2016. "Reframing the concept of alternative livelihoods." Conservation Biology 30 (1):7-13.

Yakovleva, Natalia. 2017. Corporate social responsibility in the mining industries: Routledge. 